\title{
34. SULFIDE PETROLOGY OF BASALTS FROM DEEP SEA DRILLING PROJECT HOLES 504B AND 505B 1
}

\author{
V. V. Distler, N. N. Pertsev, and V. A. Boronikhin, Institute of Geology of Ore Deposits, Petrography, \\ Mineralogy, and Geochemistry, IGEM, Academy of Sciences, Moscow, 109017, U.S.S.R.
}

\begin{abstract}
Primary sulfide mineralization in basalts of the Costa Rica Rift occurs mainly in chrome-spinel-bearing olivine tholeiites. Primary sulfides form both globules, consisting of quenched single-phase solid solutions, and irregular polymineralic segregations of pyrrhotite, chalcopyrite, cubanite, and pentlandite.

Two types of sulfide solid solutions-iron-nickel $\left(\mathrm{M}_{\mathrm{ss}}\right)$ and iron-copper $\left(\mathrm{I}_{\mathrm{ss}}\right)$-were found among sulfide globules. These types appear to have formed because of sulfide-sulfide liquid immiscibility in the host magmas; as proved by the presence of globules with a distinct phase boundary between $\mathrm{M}_{\mathrm{ss}}$ and $\mathrm{I}_{\mathrm{ss}}$. Such two-phase globules are associated with large olivine phenocrysts. Inhomogeneties among the globule composition likewise are caused by sulfide-sulfide immiscibility.

Secondary sulfides form irregular segregations and veins consisting of pyrite, marcasite, and chalcopyrite.
\end{abstract}

\section{INTRODUCTION}

During study of the ore minerals in basalts of a newly formed ocean rift zone (Costa Rica Rift, Deep Sea Drilling Project Legs 69 and 70), we paid particular attention to two groups of problems: (1) elucidation of the distribution pattern of ore minerals in certain units of basalts typical of the ocean floor, and (2) detailed investigation of the growth, mineralogy, and chemical composition of sulfides, as well as several oxides. In part, this was to provide comparison with ore-mineral associations of magmatic deposits of continents. In magmatic ore deposits, as a rule, low-temperature transformation, metamorphism, and hydrothermal alteration do not preserve primary associations of phases crystallized from melts; therefore, newly formed oceanic basalts, which have crystallized rapidly and show phenomena of rapid cooling, are important natural occurrences to study, despite the fact that sulfides usually constitute only a small part of their volume.

We studied the distribution of sulfides in DSDP Holes 504B $\left(1^{\circ} 13.63^{\prime} \mathrm{N}, 83^{\circ} 43.81^{\prime} \mathrm{W}\right)$ and 505B $\left(1^{\circ} 55.17^{\prime} \mathrm{N}\right.$, $83^{\circ} 47.29^{\prime} \mathrm{W}$ ) in all cores; however, in most studied samples sulfides were either lacking or occurred as tiny individual grains. Fourteen samples in which sulfides were most abundant were studied in detail by ore microscopy and microprobe analysis. Descriptions of the studied samples are given in the appendix, and their chemical composition is given in Etoubleau et al. (this volume).

In basalts, primary and secondary ore phases are common. They are present as rounded, homogeneous and layered globules and xenomorphic mineral aggregates which crystallize in interstices between the main rock-forming minerals, and as equant patches and veinlets replacing or crossing rock-forming minerals. Among

\footnotetext{
${ }^{1}$ Cann, J. R., Langseth, M. G., Honnorez, J., Von Herzen, R. P., White, S. M., et al., Init. Repts. DSDP, 69: Washington (U.S. Govt. Printing Office).
}

the ore aggregates are quenched iron-nickel $\left(\mathrm{M}_{\mathrm{ss}}\right)$ and iron-copper $\left(I_{s s}\right)$ sulfide solid solutions, pyrrhotite, chalcopyrite, pentlandite, and cubanite, as well as titanomagnetite, chromian spinel, and magnetite.

Secondary minerals include pyrite, nickeliferous pyrite, marcasite, oxides, and iron oxyhydroxides.

This paper deals particularly with sulfide minerals.

\section{PRIMARY SULFIDE GLOBULES}

Quenched sulfide solid solutions are among the most interesting ore minerals in basalts. They occur mainly as globules and are present in four of 13 studied samples. All four basalts are holocrystalline and contain great amounts of titanomagnetite as well.

In the majority of cases, the globules have a rather regular, rounded shape, but they almost always include numerous silicate phases which form vermicular and equant intergrowths (Plate 1); sometimes, however, the shape of globules is irregular, following the outline of neighboring crystals. This is particularly evident at contacts with titanomagnetite (Plate 2). Just at the contacts the surfaces of globules become flat (Plate 2, Figs. 1,2), their external parts retaining rounded configurations. Signs of flowing of the substance of the globules into intergranular areas of closely spaced oxide grains are markedly exhibited (Plate 2, Fig. 3). Analogous relationships are shown by growths of sulfides next to chromian spinel (Plate 2, Fig. 4).

These relations obviously prove that sulfides crystallized later than titanomagnetite and chromian spinel.

Judging from their internal structure, we distinguish single-phase and two-phase globules. One of the most interesting two-phase globules is shown in Plate 1, Figure 1 and in Plate 3. This globule was discovered as an inclusion in a large phenocryst of unzoned plagioclase $\left(A n_{81}\right)$ (Table 1). The globule has a relatively regular, rounded shape, and has magnetite inclusions in the periphery. The internal structure of the globule is characterized by a distinct boundary between two phases, 
Table 1. Chemical compositions of rock forming minerals in basalts (X-ray microprobe analysis, wt.\%).

\begin{tabular}{|c|c|c|c|c|c|c|c|c|c|c|c|}
\hline \multirow[b]{2}{*}{ Component } & \multirow[b]{2}{*}{$\begin{array}{l}504 \mathrm{~B}-7-3, \\
106-126^{\mathrm{a}}\end{array}$} & \multirow[b]{2}{*}{$\begin{array}{l}504 \mathrm{~B}-7-3 \\
116-120^{\mathrm{b}}\end{array}$} & \multicolumn{6}{|c|}{ Plagioclase } & \multirow{2}{*}{$\begin{array}{l}\text { Olivine } \\
505 \mathrm{~B}-2-1 \\
29-33^{\mathrm{a}}\end{array}$} & \multicolumn{2}{|c|}{ Clinopyroxene } \\
\hline & & & $\begin{array}{l}504 \mathrm{~B}-7-3 \\
116-120^{\mathrm{b}}\end{array}$ & $\begin{array}{l}505 \mathrm{~B}-2-1 \\
29-33^{\mathrm{b}}\end{array}$ & $\begin{array}{c}505 \mathrm{~B}-2-1, \\
29-33^{\mathrm{b}}\end{array}$ & $\begin{array}{l}505 \mathrm{~B}-6-1, \\
112-114^{\mathrm{a}}\end{array}$ & $\begin{array}{l}505 \mathrm{~B}-6-1, \\
112-114^{\mathrm{a}}\end{array}$ & $\begin{array}{l}505 \mathrm{~B}-6-1, \\
112-114^{\mathrm{a}}\end{array}$ & & $\begin{array}{l}504 \mathrm{~B}-7-3, \\
106-126^{\mathrm{a}}\end{array}$ & $\begin{array}{l}504 \mathrm{~B}-7-3 \\
106-126^{\mathrm{b}}\end{array}$ \\
\hline $\mathrm{SiO}_{2}$ & 46.88 & 49.18 & 45.18 & 46.17 & 50.10 & 43.29 & 43.94 & 47.66 & 41.72 & 52.55 & 52.92 \\
\hline $\mathrm{TiO}_{2}$ & - & - & - & - & - & - & - & - & - & 0.36 & 0.90 \\
\hline $\mathrm{Al}_{2} \mathrm{O}_{3}$ & 32.11 & 30.71 & 33.56 & 33.60 & 31.09 & 36.27 & 37.33 & 31.79 & - & 3.46 & 3.93 \\
\hline $\mathrm{Cr}_{2} \mathrm{O}_{3}$ & - & - & - & - & - & - & - & - & - & 0.43 & 0.05 \\
\hline $\mathrm{FeO}$ & - & - & - & - & - & - & - & - & 17.08 & 4.86 & 8.68 \\
\hline $\mathrm{NiO}$ & - & - & - & - & - & - & - & - & 0.11 & 0.06 & 0.05 \\
\hline $\mathrm{MnO}$ & - & - & - & - & - & - & - & - & 0.32 & 0.16 & 0.24 \\
\hline $\mathrm{CaO}$ & 16.43 & 15.75 & 17.93 & 16.89 & 14.95 & 19.16 & 19.46 & 16.52 & - & 18.31 & 19.78 \\
\hline $\mathrm{MgO}$ & - & - & - & - & - & - & - & - & 42.56 & 18.06 & 14.91 \\
\hline $\mathrm{K}_{2} \mathrm{O}$ & - & - & - & - & - & - & - & 0.02 & - & - & - \\
\hline $\mathrm{Na}_{2} \mathrm{O}$ & 2.16 & 2.41 & 1.59 & 1.94 & 2.74 & 0.80 & 0.81 & 2.13 & - & 0.32 & 0.39 \\
\hline Total & 97.58 & 98.05 & 98.26 & 98.60 & 98.88 & 99.52 & 101.54 & 98.2 & 100.78 & 98.57 & 101.85 \\
\hline An $(\%)$ & 81 & 76 & 86 & 83 & 75 & 93 & 93 & 81 & & & \\
\hline
\end{tabular}

Note: Sample designations are standard (interval in $\mathrm{cm}$ ).

${ }^{\text {a }}$ Phenocryst.

b Microlite.

c Outer part of zoned crystal.

$\mathrm{d}$ Inner part of zoned crystal.

which occupy approximately equal volumes of the globule. A yellowish-white phase, standing apart in the upper section, forms a relatively thin rim along the peripheral part of the globule, surrounding a pinkish-white phase which fills the bottom of the globule. Both parts of the globule are made up of quenched sulfide solid solutions which are unexsolved, and yet vary sharply in chemical composition (Plate 3; Table 2). The upper part of the globule consists of iron-copper-sulfide solid solution $\left(\mathrm{I}_{s s}\right)$ with subordinate amounts of nickel and cobalt, whereas the bottom part is iron-nickel-sulfide solid solution $\left(\mathrm{M}_{\mathrm{ss}}\right)$ with subordinate amounts of copper and cobalt. The iron-nickel sulfide solid solution has more sulfur. It should be emphasized that despite the low concentrations of cobalt, its abundance in the iron-nickel phase is twice that in the iron sulfide phase. In the ironcopper part, the distribution of elements is relatively uniform; in the iron-nickel phase, nickel and sulfur are enriched at the bottom of the globule (Plate 3), and the globule is enriched in nickel at the boundary of the iron-nickel and iron sulfide solid solutions.

Calculations of structural formulas from analyses given in Table 2 indicate that the iron-copper-sulfide solid solution is stoichiometric, with a metal/sulfur ratio close to 1.0 ; the proportions of metallic components correspond to the general formula of the solid solution $\left(\mathrm{Cu}_{0.87}\right.$ $\left.\mathrm{Ni}_{0.13}\right)_{1.0} \mathrm{Fe}_{2.0} \mathrm{~S}_{3.08}$, close to the proportions of components in cubanite. The iron-nickel solid solution is characterized by an abundance of stoichiometric sulfur, with a metal/sulfur ratio of 0.80 . The proportions of metallic components correspond to the formula of sulfur-rich nickel-pyrrhotite solid solution $\left[\mathrm{Fe}_{0.60} \mathrm{Ni}_{0.19}(\mathrm{Co}, \mathrm{Cu})_{0.01}\right]$ $\mathrm{S}_{0.80}$. A local increase of nickel content in some places evidently is connected with an increase of sulfur content at the edge of the globule.

Numerous globules observed in other parts of the basalt section under study have less-distinct phase correlations; commonly one of the sulfide solid solutions is predominant, whereas the second one occupies a rather small volume (Plate 1, Fig. 2). This type of globule is transitional to single-phase globules and is widespread. Morphologically, these globules do not differ from twophase globules; they also contain numerous silicate inclusions.

Some globules also are made up of iron-nickel and iron-copper solid solutions. These usually are localized within the basalt groundmass, whereas iron-nickel and two-phase globules more often are associated with phenocrysts. Of all the studied globules, those having ironcopper solid solutions are the most homogeneous in chemical composition. Besides principal components, they contain up to $2.5 \%$ nickel and not more than $0.2 \%$ cobalt. In all the iron-copper globules studied, the met$\mathrm{al} /$ sulfur ratio as well as the proportions of the various metals correspond to cubanite.

Iron-nickel solid solutions are more diverse in composition with variable proportions of metallic components and variable metal/sulfur ratios.

\section{MULTI-PHASE SULFIDE AGGREGATES}

Multi-phase sulfide aggregates are common in the lower part of Hole 504B. They occur in holocrystalline basalts and usually are associated with grain-boundary interstices of rock-forming silicates. Sulfide aggregates can coexist with ore globules or occur separately. Aggregates commonly consist of pyrrhotite, pentlandite, chalcopyrite, cubanite, and magnetite (Plate 4).

\section{Pyrrhotite}

Pyrrhotite is the most common mineral among these sulfide intergrowths. Usually it forms relatively large single crystals containing numerous pentlandite intergrowths. The composition of pyrrhotite is uniform (Table 2). Constant components are nickel (0.3-1.0 wt. \%) and cobalt $(0.12-0.25$ wt. \%); copper is rare. Structural formulas calculated from microprobe analyses indicate 
Table 1. (Continued).

\begin{tabular}{|c|c|c|c|c|c|c|c|c|c|}
\hline \multicolumn{2}{|c|}{ Clinopyroxene } & \multicolumn{4}{|c|}{ Chromian Spinel } & \multicolumn{2}{|c|}{ Titanomagnetite } & \multicolumn{2}{|c|}{ Smectite } \\
\hline $\begin{array}{l}\text { 505B-2-1, } \\
29-33^{\mathrm{b}}\end{array}$ & $\begin{array}{l}\text { 505B-6-1, } \\
112-114\end{array}$ & $\begin{array}{c}504 \mathrm{~B}-7-5 \\
68-72\end{array}$ & $\begin{array}{l}505 \mathrm{~B}-6-1, \\
112-114\end{array}$ & $\begin{array}{l}\text { 505B-6-1, } \\
112-114^{\mathrm{c}}\end{array}$ & $\begin{array}{l}505 \mathrm{~B}-6-1 \\
112-114^{d}\end{array}$ & $\begin{array}{c}504 \mathrm{~B}-51-1, \\
18-20\end{array}$ & $\begin{array}{c}504 \mathrm{~B}-51-1, \\
18-20\end{array}$ & $\begin{array}{c}504 \mathrm{~B}-51-1 \\
18-20\end{array}$ & $\begin{array}{c}504 \mathrm{~B}-51-1, \\
18-20\end{array}$ \\
\hline 50.87 & 49.72 & 4.0 & 4.64 & 5.02 & 5.30 & 5.37 & 5.38 & 54.28 & 57.80 \\
\hline 1.08 & - & 0.38 & 0.40 & 0.43 & 0.41 & 18.12 & 17.76 & 0.55 & 0.47 \\
\hline 4.10 & 5.36 & 28.46 & 28.23 & 28.92 & 30.84 & 3.80 & 3.71 & 12.74 & 14.04 \\
\hline 0.08 & 0.24 & 34.16 & 34.78 & 33.95 & 31.91 & - & - & - & - \\
\hline 9.89 & 10.29 & 17.66 & 16.81 & 16.29 & 17.15 & 68.81 & 68.75 & 11.94 & 7.81 \\
\hline 0.05 & - & - & - & - & - & - & - & - & - \\
\hline 0.29 & 0.30 & 0.29 & 0.28 & 0.29 & 0.28 & 0.64 & 0.64 & 0.22 & 0.29 \\
\hline 16.41 & 19.35 & - & - & - & - & - & - & 4.60 & 3.59 \\
\hline 15.87 & 14.52 & 13.75 & 14.58 & 14.45 & 15.04 & 1.80 & 1.95 & 10.36 & 11.22 \\
\hline- & - & - & - & - & - & - & - & 0.05 & 0.10 \\
\hline 0.62 & 0.46 & - & - & - & - & - & - & 2.98 & 2.98 \\
\hline 99.26 & 101.06 & 98.54 & 99.72 & 99.35 & 100.93 & 98.54 & 98.18 & 97.72 & 98.10 \\
\hline
\end{tabular}

Table 2. Chemical composition of sulfides (X-ray microprobe analysis, wt. \%).

\begin{tabular}{|c|c|c|c|c|c|c|c|c|}
\hline $\begin{array}{c}\text { Sample } \\
\text { (interval in } \mathrm{cm} \text { ) }\end{array}$ & $\begin{array}{c}\text { Analysis } \\
\text { No. }\end{array}$ & $\begin{array}{c}\text { Phase } \\
\text { (see text) }\end{array}$ & $\mathrm{Fe}$ & $\mathrm{Ni}$ & Co & $\mathrm{Cu}$ & s & Total \\
\hline \multirow[t]{3}{*}{$505 \mathrm{~B}-2-1,29-33$} & 1 & Pyrite & 40.81 & 4.43 & 0.73 & - & 51.83 & 97.80 \\
\hline & 2 & $\mathrm{M}_{\mathrm{ss}}{ }^{\mathrm{a}}$ & 49.38 & 7.11 & 0.33 & 0.67 & 38.87 & 96.35 \\
\hline & 3 & & 39.36 & 1.18 & 1.15 & 22.63 & 33.60 & 96.92 \\
\hline \multirow[t]{4}{*}{ 505B-6-1, 112-114 } & 4 & $\mathrm{M}_{\mathrm{ss}}{ }^{\mathrm{a}}$ & 43.45 & 14.61 & 0.28 & 0.30 & 41.49 & 100.13 \\
\hline & 5 & $1_{s s^{*}}^{*}$ & 41.01 & 2.68 & 0.14 & 20.14 & 36.27 & 100.24 \\
\hline & 6 & $I_{\text {ss }}$ & 42.25 & 2.27 & 0.12 & 18.91 & 33.71 & 97.25 \\
\hline & 7 & $I_{s s}$ & 39.88 & 2.23 & 0.12 & 19.60 & 36.36 & 98.20 \\
\hline 504B-5-2, 112-115 & 8 & Pyrite & 46.41 & 0.09 & 0.06 & - & 48.84 & 95,40 \\
\hline \multirow[t]{2}{*}{$504 \mathrm{~B}-6-2,99-101$} & 9 & Pyrite & 46.59 & 0.27 & 0.06 & - & 51.88 & 98.79 \\
\hline & 10 & Pyrite & 46.13 & 1.24 & 0.10 & - & 53.05 & 100.52 \\
\hline \multirow[t]{2}{*}{$504 \mathrm{~B}-7-3,116-120$} & 11 & Pyrite & 42.89 & 1.35 & 0.06 & - & 50.14 & 94.44 \\
\hline & 12 & Pyrite & 35.99 & 8.09 & 0.72 & - & 50.14 & 94.94 \\
\hline \multirow[t]{2}{*}{$504 \mathrm{~B}-13-4,7-10$} & 13 & Pyrite & 46.91 & 0.58 & 0.16 & - & 50.02 & 97.67 \\
\hline & 14 & Pyrite & 47.34 & 0.73 & 0.16 & - & 50.14 & 98.38 \\
\hline \multirow[t]{7}{*}{$504 \mathrm{~B}-18-1,84-86$} & 15 & Pyrite & 47.27 & 1.01 & 0.10 & - & 52.82 & 101.20 \\
\hline & 16 & Pyrite & 42.49 & 4.18 & 0.18 & - & 51.60 & 98.45 \\
\hline & 17 & Pyrite & 44.29 & 2.76 & 0.16 & - & 52.40 & 99.24 \\
\hline & 18 & Pyrite & 42.75 & 3.47 & 0.28 & - & 50.69 & 97.20 \\
\hline & 19 & Pyrite & 46.43 & 1.24 & 0.28 & - & 50.52 & 98.56 \\
\hline & 20 & Pyrite & 46.75 & 1.05 & 0.10 & - & 52.85 & 100.75 \\
\hline & 21 & Pyrite & 45.70 & 2.17 & 0.16 & - & 53.22 & 101.35 \\
\hline \multirow[t]{4}{*}{$504 \mathrm{~B}-18-2,100-102$} & 22 & Pyrite & 47.36 & 0.75 & 0.13 & - & 50.20 & 98.44 \\
\hline & 23 & Pyrite & 47.87 & 0.51 & 0.13 & - & 50.71 & 99.16 \\
\hline & 24 & Pyrite & 48.81 & 0.57 & 0.08 & - & 52.44 & 101.91 \\
\hline & 25 & Pyrite & 46.03 & 2.65 & 0.33 & - & 52.48 & 101.50 \\
\hline $504 \mathrm{~B}-26-1,86-89$ & 26 & Pyrite & 42.55 & 0.96 & 1.10 & 1.29 & 52.25 & 98.15 \\
\hline \multirow[t]{4}{*}{ 504B-36-3, $120-123$} & 27 & Pyrrhotite & 59.16 & 0.33 & 0.19 & - & 38.29 & 97.97 \\
\hline & 28 & Pyrrhotite & 57.55 & 0.40 & 0.16 & - & 38.62 & 96.72 \\
\hline & 29 & Chalcopyrite & 29.10 & 0.41 & 0.21 & 29.18 & 33.62 & 92.51 \\
\hline & 30 & $1_{\text {ss }}$ & 38.74 & 2.42 & 0.75 & 21.80 & 37.93 & 100.91 \\
\hline \multirow[t]{7}{*}{$504 \mathrm{~B}-41-4,42-45$} & 31 & Pyrrho & 58.23 & 0.48 & 0.18 & - & 38.70 & 97.59 \\
\hline & 32 & Pyrrhotite & 59.00 & 0.76 & 0.13 & - & 38.63 & 98.52 \\
\hline & 33 & Pyrtt & 58.08 & 1.01 & 0.17 & - & 39.29 & 98.55 \\
\hline & 34 & Pyrthotite & 58.81 & 0.62 & 0.12 & 0.12 & 37.05 & 95.73 \\
\hline & 35 & Pyrrhotite & 58.56 & 0.48 & 0.13 & 0.05 & 36.65 & 95.88 \\
\hline & 36 & $I_{85}$ & 36.34 & 2.98 & 0.17 & 21.07 & 34.01 & 94.57 \\
\hline & 37 & $\mathrm{M}_{\mathrm{ss}}$ & 26.89 & 18.23 & 1.97 & 15.69 & 34.25 & 97.31 \\
\hline \multirow[t]{4}{*}{$504 \mathrm{~B}-51-1,18-20$} & 38 & $I_{s s}$ & 34.83 & 1.88 & 0.23 & 24.71 & 33.05 & 94.71 \\
\hline & 39 & Pyrrhotite & 58.38 & 0.80 & 0.15 & - & 40.13 & 99.57 \\
\hline & 40 & Pyrrho & 58.99 & 0.59 & 0.17 & - & 38.62 & 98.37 \\
\hline & 41 & Pyrrhotite & 59.11 & 0.29 & 0.20 & - & 39.05 & 98.65 \\
\hline \multirow[t]{3}{*}{ 504B-57-3, 107-110 } & 42 & Pyrrho & 58.16 & 0.71 & 0.22 & - & 37.29 & 96.39 \\
\hline & 43 & Pyrrhotite & 58.71 & 0.57 & 0.20 & - & 39.23 & 98.71 \\
\hline & 44 & Chalcopyrite & 28.13 & 0.10 & 0.08 & 32.00 & 32.78 & 93.09 \\
\hline \multirow[t]{5}{*}{$504 \mathrm{~B}-70-1,45$} & 45 & Pyrrhotite & 57.60 & 0.54 & 0.22 & - & 38.07 & 96.46 \\
\hline & 46 & Pyrrho & 56.86 & 0.55 & 0.25 & - & 39.74 & 97.37 \\
\hline & 47 & Pyrrhotite & 57.57 & 0.64 & 0.24 & - & 38.58 & 97.03 \\
\hline & 48 & Pyrrho & 57.46 & 0.61 & 0.25 & - & 38.32 & 96.63 \\
\hline & 49 & Pyrrhotite & 58.70 & 0.56 & 0.15 & - & 38.02 & 97.53 \\
\hline
\end{tabular}

a Two-phase globules.

that pyrrhotite is among the high-sulfur sulfides, having a metal/sulfur ratio near that of monoclinic pyrrhotite.

\section{Chalcopyrite}

Chalcopyrite is usually less abundant than pyrrhotite in sulfide aggregates. It forms irregularly-shaped equant grains, many of which contain lamellar intergrowths of cubanite. The small size of chalcopyrite inclusions al- lowed us to analyze only single grains (Table 2). In composition and optical properties, the mineral corresponds to stoichiometric tetragonal chalcopyrite. It contains up to $0.4 \%$ nickel and up to $0.2 \%$ cobalt.

\section{Pentlandite}

This mineral occurs as inclusions in two forms. The first type includes equant aggregates and rims on the peripheries of sulfide intergrowths or at the boundaries of sulfides and silicates; other such rims are also along the boundaries of pyrrhotite and chalcopyrite grains. The second form of pentlandite is lamellar intergrowths in pyrrhotite; the pentlandite content in individual pyrrhotite grains varies. The small size of grains prohibited determination of mineral composition.

\section{Cubanite}

Cubanite is widespread in the sulfide intergrowths although it is not present in all intergrowths. It was identified by its notable optical properties-those of color and anisotropy-but its composition was not determined, because of the small size of inclusions. Cubanite occurs only with chalcopyrite, forming tiny lamellar intergrowths within it.

\section{SECONDARY SULFIDES}

Secondary sulfides are the most widespread ore minerals in these basalts. They were found in both studied holes and occur predominantly in units of the lower parts of the basement. With development of secondary sulfides, primary sulfides usually disappear.

\section{Pyrite}

Pyrite is predominant among secondary sulfides. It forms irregular grains, including equant and veinlet-like aggregates unevenly distributed in the basalt mesostasis. Pyrite also has replaced both primary sulfides and titanomagnetite. Plate 2, Figure 4 shows a pyrite pseudomorph after a pyrrhotite globule; Plate 5, Figure 1 shows a skeletal titanomagnetite crystal in pyrite.

Pyrites have variable nickel concentrations and lessvariable cobalt content (Table 2). Some pyrites contain only $0.1 \%$ nickel and $0.01 \%$ cobalt; others contain up 
to $8 \%$ nickel and $0.7 \%$ cobalt. The uniform distribution of both metals is characteristic for such grains and differs from the zonal structure common to nickel-bearing pyrite. The majority of studied grains contain 1 to $4 \%$ $\mathrm{Ni}$ and 0.1 to $0.3 \%$ Co.

\section{Marcasite}

Secondary sulfide minerals include marcasite as well. The mineral is more rare than pyrite; unlike pyrite, marcasite occurs mainly as veinlets. It is sometimes observed as a single-mineral a,ggregate, as well as in growths with pyrite, and rarely with chalcopyrite.

\section{OXIFES}

Oxide ore minerals-titanomagnetite and chromium spinels - are nearly ubiquitous in basalts of Holes 504B and 505B. Samples which lack oxide minerals (because of alteration) generally have no sulfides either. In some cases, samples contain oxides but lack sulfides.

\section{Titanomagnetite}

Titanomagnetite is the most widespread oxide mineral in the studied basalts; in places it represents several percent of the rock. Titanomagnetite is found in the groundmass of basalts and is distinctly xenomorphic in relation to plagioclase and pyroxene. Its dominant morphology is skeletal (Plate 2, Figs. 1-3). These forms are typical of titanomagnetite in oceanic basalts and have been described in many previous papers. As mentioned above, titanomagnetite formed earlier than sulfides in these basalts, and its habit governs the shape of some sulfide globules.

Lack of exsolution phenomena and the absence of ilmenite exsolution lamellae are characteristic of this titanomagnetite and typify basalts altered at elevated temperatures.

The composition of titanomagnetite is not unusual. The mineral contains $2 \% \mathrm{MgO}$ and $0.6 \% \mathrm{MnO}$. The analyses show some silica and alumina, because it was difficult to analyze these tiny grains, and adjacent silicate phases were partially encountered by the probe beam (Table 1).

\section{Chromian Spinel}

Chromian spinel occurs in these basalts usually as euhedral isolated grains. Some of the grains are typical phenocrysts (Plate 5; Fig. 2) and occur within olivine. Other grains are found in the mesostasis as euhedral crystals. The spinels evidently crystallized before olivine and plagioclase.

Spinels developed earlier than sulfides as well (Plate 2, Fig. 4). Some have thin rims of titanomagnetite, indicating that mineral formed later (Furuta and Tokuyama, this volume).

For the most part, spinel grains do not vary significantly in composition (Table 1). They have magnesiochromite compositions, with some alumina, and are low in titania. Several coarse grains are optically zoned, having optically lighter rims. Some contain a great number of silicate intergrowths not present in the central parts of grains (Plate 5, Fig. 2). Small, rounded silicate inclusions occur in the central part. The rim zone has higher alumina and lower iron and chromium contents (Table 1). The magnesium concentration is constant. Details of spinel compositions and zoning are given in Furuta and Tokuyama (this volume).

\section{Magnetite}

In the studied basalts, mangetite occupies a definite structural position: it is not found among silicate minerals, and is associated only with sulfides. Magnetite, as a rule, does not occur in globules. The only exception is a two-phase globule (Plate 1, Fig. 1) in which magnetite forms tiny euhedral crystals along the periphery of the globule.

Most often, magnetite occurs in multi-phase sulfide aggregates. It forms rounded, irregular inclusions in pyrrhotite, and is rarer in other sulfides. We were unable to obtain complete microprobe analyses of magnetite, because of its small grain size. Qualitative analysis demonstrated, however, that magnetite intergrown with sulfides does not contain titanium and is homogeneous.

\section{DISCUSSION}

Study of the chemical and mineralogical composition of basalts of Holes 505B and 504B shows that those bearing primary sulfides have distinct petrological features. According to chemical composition, the basalts are olivine tholeiites with high $\mathrm{MgO}$ contents. The main feature of the rocks is that the earliest stages of their crystallization were characterized by olivine $\left(\mathrm{Fo}_{88}\right)$, plagioclase $\left(\mathrm{An}_{83-93}\right)$, and $\mathrm{Cr}$-spinel. This paragenesis is characteristic of almost all continental magmatic rocks which bear sulfide ore-nickel mineralization. The spinels in the studied basalts are magnesiochromites, which also are typical of sulfide-bearing magmatic rocks on continents. A high concentration of chromium in the original basalt magmas also accounts for its considerable enrichment in magnesian clinopyroxene phenocrysts $(\mathrm{Cr}$ concentration reaches $0.5 \%$; Table 1$)$. Clinopyroxenes in the groundmass have less than $0.1 \% \mathrm{Cr}_{2} \mathrm{O}_{3}$ (Table 1); they are higher in iron and alumina content and are titanium-rich. The adjacent plagioclase has the compositional range $\mathrm{An}_{75-76}$. Aspects of the distribution of sulfide aggregates in basalts lead to the conclusion that different types of aggregates are associated with different silicate parageneses.

One can find in association with silicate phenocrysts two-phase globules, or globules in which iron-nickel sulfide solid solution predominates. Globules in the basalt mesostasis more often consist of iron-copper solid solution. Elsewhere, multi-phase sulfide aggregates are present instead of quenched sulfide solid solutions. These data prove that the basalt melts contained sulfide liquids varying in composition. This conclusion is not a new one. Several researchers (Skinner and Peck, 1969; Czamanske and Moore, 1977) have demonstrated that, in one and the same basalt, sulfides differ systematically in their ratios of copper to nickel, depending on when they formed and with what silicates they occurred as the 
rock crystallized. Our data on the composition of sulfide mineralization in basalts of the Costa Rica Rift zone agree with the results of Czamanske and Moore (1977), who found that nickel is predominant in the earlier sulfide aggregates, and copper in the later ones. Our results, however, contradict the data of Skinner and Peck (1969). The problem is not so much one of deducing sulfide liquid compositions which correspond to early or late sulfides, but rather one of understanding why there are systematic differences in sulfide-liquid compositions.

There is no doubt that sulfide liquid compositions are related to changes in basalt melt composition as crystallization proceeds. The appearance of early solid phases, the decrease in temperature in the process of crystallization, and changes in oxygen fugacity in the melt sequentially alter conditions of exchange between silicate and sulfide melt components. These factors also change the fugacity of the sulfur in the sulfide liquids, which naturally affects the composition of sulfides in the process of crystallization. These factors account for the wide variations in the composition of quenched sulfide solid solutions observed by us and by Skinner and Peck (1969). These variations are observed in a range of $M_{s s}$ compositions $(7-18 \% \mathrm{Ni} ; 0.2-2.0 \% \mathrm{Co} ; 34-41 \% \mathrm{~S})$, and in $\mathrm{I}_{\mathrm{ss}}$ compositions $(1-3 \% \mathrm{Ni} ; 19-24 \%$ Co; etc.). The composition of pyrrhotite found in different globules or in aggregates is more constant, although there are small variations in nickel content in solid solution $(0.2-1.0 \%)$. Variations in multi-phase sulfide aggregates are expressed as differences in the proportions of chalcopyrite and exsolved cubanite, and in the change in abundance of lamellar pentlandite in pyrrhotite.

We point out that our findings on phase relations and on variations in the composition of separate phases are in full agreement with experimental data on systems modeling natural sulfide systems (Craig and Kullerud, 1969).

Let us now consider other possible causes for differences in the composition of the sulfide aggregates. The presence of sulfide globules as inclusions in earlyformed crystals of plagioclase is one more demonstration that sulfide liquid is an immiscible component of basalt melts. In our opinion, two immiscibile phases, one sulfide, the other silicate, existed from the time of segregation in the upper mantle to the time of crystallization of lava on the sea floor. We see no reason to suppose that sulfides should originally have been dissolved in the magmas under the thermodynamic conditions prevailing in the upper mantle, and then separated from the magma as immiscible liquids. We think that immiscibility is explained by the fact that certain metals in basalt melt have mainly metal-sulfur bonds, rather than metal-oxygen or metal-silica.

Successive stages of basalt melt evolution (i.e., fractionation) led to segregation of metal-sulfur groups. Upon reaching sufficient concentrations, discrete boundaries formed between these groups and the silicate melt. This did not occur all at once, but over a range of melt compositions. Thus, isolated sulfides with variable compositions emerged at different times and in different places of the same basalt melt.

In addition, the inhomogeneities in the compositions of sulfide aggregates may be a result of the existence of more than one liquid sulfide phase. This is mainly confirmed by the occurrence of two-phase sulfide globules. Phase relations in these globules prove that at least by the time of crystallization of silicate phenocrysts there were already two separate iron- and nickel-rich sulfide liquids. Iron-nickel-sulfide solid solution crystallized first, iron-copper-sulfide solid solutions next. Both solid solutions were rapidly cooled, but there are no data to explain why either kind of solid solution lacks exsolution phenomena. One may assume that initially sulfidesulfide immiscibility existed under conditions of high melt temperatures. With decrease in temperature the most important process occurring in sulfide liquids became crystallization differentiation. This governed phase relations in multi-phase sulfide aggregates associated with the mesostasis in basalts, as mentioned above. Despite these late-stage effects, the existence of sulfidesulfide immiscibility itself has been demonstrated and is extremely important.

These considerations may explain the phenomenon of two-phase pyrrhotite-chalcopyrite phenocrysts, which are widespread in such copper-nickel deposits as Norilsk. The same data may account, to a certain degree, for the inhomogeneity of sulfide aggregates in the Norilsk deposits (Genkin et al., 1977; Distler et al., 1979). The data, however may be most important in offering an explanation for the zoning of massive sulfide ores (Distler et al., 1975). Study of this zoning has led to the conclusion that isolation of large masses of pyrrhotite and chalcopyrite (talnakhite and mooihoekite ores) was not a result of crystallization differentiation, but seem to be caused by layering of sulfide melt. Layering in this case evidently proceeded under high temperatures because with decrease in temperature a reaction between iron-ore and iron-nickel melts occurred, forming widespread cubanite. Part of the cubanite, as our data confirm, might have crystallized directly from the melt.

Thus, study of sulfide mineralization of oceanic basalts can be extremely valuable for the understanding of certain important features of copper-nickel ores associated with platform basaltic bodies. Our comparison shows that both occurrences have similar sulfide components, and that evolution of sulfide-silicate melts is governed by uniform processes.

\section{REFERENCES}

Craig, J. R., and Kullerud, G., 1969. Phase relations in the $\mathrm{Cu}-\mathrm{Fe}-$ $\mathrm{Ni}-\mathrm{S}$ system and their application to magmatic ore deposits. In Wilson, H. D. B. (Ed.), Magmatic Ore Deposits. Econ. Geol. Monogr., 4:344-358.

Czamanske, G. K., and Moore, J. G., 1977. Composition and phase chemistry of sulfide globules in basalt from the Mid-Atlantic Ridge rift Valley near $37^{\circ} \mathrm{N}$ latitude. Geol. Soc. Am. Bull., 88: 587-599. 


\section{V. DISTLER, N. N. PERTSEV, V. A. BORONIKHIN}

Distler, V. V., Genkin, A. D., Philimonova, A. A., Laputina, T. P., and Khitrov, V. G., 1975. Zonality of copper-nickel ores of Talnakh and October deposits. Geol. Ore Deposits, 2:16-27.

Distler, V. V., Smirnov, A. V., Grokhovskaya, T. L., Muravitskaya, G. N., and Philimonova, A. A., 1979. Stratification, cryptolayering of differentiated intrusions and conditions of formation of sulphide mineralization. In Smirnov, V. T. (Ed.), Conditions of Formation of Magmatic Ore Deposits: Moscow (Nauka), pp. 211-269.
Genkin, A. D., Kovalenker, V. A., Smirnov, A., and Muravitskaya, G. N., 1977. Peculiarities of the composition of Norilsk disseminated ores and their genetic importance. Geol. Ore Deposits, 1: 24-38.

Skinner, B. J., and Peck, D. L., 1969. An immiscible sulfide melt from Hawaii. In Wilson, H. D. B. (Ed.), Magmatic Ore Deposits. Econ. Geol. Monogr., 4:310-322.

\section{APPENDIX}

Petrographic Characteristics of Samples and Distribution of Sulfides in Holes 504B and 505B

\begin{tabular}{|c|c|c|c|c|}
\hline $\begin{array}{l}\text { Sample } \\
\text { (interval in } \mathrm{cm} \text { ) }\end{array}$ & $\begin{array}{l}\text { Sample } \\
\text { No. }\end{array}$ & $\begin{array}{l}\text { Lithologic } \\
\text { Unit }\end{array}$ & Petrographic Characteristics & $\begin{array}{l}\text { Main } \\
\text { Ore } \\
\text { Minerals }\end{array}$ \\
\hline 504B-5-2, 112-115 & 384 & $2 \mathrm{~A}$ & $\begin{array}{l}\text { Chromite-bearing porphyritic, fine-grained, } \\
\text { holocrystalline basalt with phenocrysts of } \\
\text { plagioclase and olivine entirely replaced by } \\
\text { smectite; the internal part of a massive } \\
\text { flow. }\end{array}$ & $\begin{array}{l}\text { Spinel, } \\
\text { titanomagnetite, } \\
\text { pyrite }\end{array}$ \\
\hline 504B-6-2, 99-101 & 422 & 2B & $\begin{array}{l}\text { Chromite-bearing, microphyric, fine-grained, } \\
\text { holocrystalline basalt with phenocrysts of } \\
\text { plagioclase and olivine entirely replaced by } \\
\text { smectite. }\end{array}$ & $\begin{array}{l}\text { Spinel, } \\
\text { titanomagnetite, } \\
\text { pyrite }\end{array}$ \\
\hline $504 \mathrm{~B}-7-3,116-120$ & 488 & 2D & $\begin{array}{l}\text { Chromite-bearing, fine-grained, holocrystalline } \\
\text { basalt with phenocrysts of plagioclase and } \\
\text { olivine replaced by smectite and rare glo- } \\
\text { merocrysts of clinopyroxene. }\end{array}$ & $\begin{array}{l}\text { Spinel, } \\
\text { titanomagnetite, } \\
\text { pyrite }\end{array}$ \\
\hline $504 \mathrm{~B}-7-5,68-72$ & 515 & $2 \mathrm{D}$ & $\begin{array}{l}\text { Moderately plagioclase-olivine phyric coarse- } \\
\text { grained basalt. }\end{array}$ & $\begin{array}{l}\text { Titanomagnetite, } \\
\text { spinel }\end{array}$ \\
\hline $504 \mathrm{~B}-13-4,7-10$ & 802 & $3 \mathrm{~A}$ & $\begin{array}{l}\text { Fine-grained, holocrystalline basalt with pheno- } \\
\text { crysts of plagioclase and olivine and acces- } \\
\text { sory augite. }\end{array}$ & Pyrite \\
\hline 504B-18-1, 84-86 & 1091 & 5 & $\begin{array}{l}\text { Microphyric pillow basalt with phenocrysts of } \\
\text { plagioclase and olivine replaced by light- } \\
\text { colored smectite. }\end{array}$ & Pyrite \\
\hline $504 \mathrm{~B}-18-2,100-102$ & 1112 & 5 & $\begin{array}{l}\text { Microphyric pillow basalt with microlitic } \\
\text { groundmass and phenocrysts of plagioclase } \\
\text { and olivine replaced by smectite. }\end{array}$ & Pyrite \\
\hline 504B-26-1, 86-89 & 1455 & 17 & $\begin{array}{l}\text { Microphyric basalt with microlitic groundmass } \\
\text { and phenocrysts of plagioclase, olivine, and } \\
\text { clinopyroxene; olivine is replaced by bright- } \\
\text { green and brown-green celadonite; a mas- } \\
\text { sive flow. }\end{array}$ & Pyrite \\
\hline $504 \mathrm{~B}-36-3,120-123$ & 325 & 24 & $\begin{array}{l}\text { Coarse-grained, holocrystalline basalt with } \\
\text { phenocrysts of plagioclase, clinopyroxene, } \\
\text { and olivine partly replaced by light-colored } \\
\text { smectite; a massive flow. }\end{array}$ & $\begin{array}{l}\text { Titanomagnetite, } \\
\text { pyrrhotite, } \\
\text { chalcopyrite, } \\
\text { pentlandite, } \\
\text { I }_{\text {SS, magnetite }}\end{array}$ \\
\hline $504 \mathrm{~B}-41-4,42-45$ & 582 & 27 & $\begin{array}{l}\text { Pillow lavas and thin flows; coarse-grained, } \\
\text { holocrystalline basalt with phenocrysts of } \\
\text { plagioclase, clinopyroxene, and olivine re- } \\
\text { placed by olive-green smectite. }\end{array}$ & $\begin{array}{l}\text { Spinel, } \\
\text { titanomagnetite, } \\
\text { pyrrhotite, } \\
\text { chalcopyrite, } \\
\text { pentlandite, I } \\
\mathrm{M}_{\mathrm{SS}}\end{array}$ \\
\hline $504 \mathrm{~B}-51-1,18-20$ & 972 & 35 & $\begin{array}{l}\text { Moderately plagioclase-olivine phyric sub- } \\
\text { ophitic coarse-grained basalt. }\end{array}$ & $\begin{array}{l}\text { Titanomagnetite, } \\
\text { pyrrhotite, } \\
\text { chalcopyrite, } \\
\text { pentlandite, } \mathrm{I}_{\mathrm{SS}}\end{array}$ \\
\hline $504 \mathrm{~B}-57-3,107-110$ & 1178 & 37 & $\begin{array}{l}\text { Coarse-grained, holocrystalline, aphyric basalt; } \\
\text { a massive flow. }\end{array}$ & $\begin{array}{l}\text { Titanomagnetite, } \\
\text { pyrrhotite, } \\
\text { chalcopyrite, } \\
\text { pentlandite }\end{array}$ \\
\hline $504 \mathrm{~B}-66-2,57-60$ & 1512 & 46 & $\begin{array}{l}\text { Coarse-grained, holocrystalline basalt; a mas- } \\
\text { sive flow. }\end{array}$ & $\begin{array}{l}\text { Titanomagnetite } \\
\text { pyrrhotite, } \\
\text { chalcopyrite }\end{array}$ \\
\hline $504 \mathrm{~B}-70-1,45$ & 1553 & 49 & $\begin{array}{l}\text { Moderately plagioclase-olivine-clinopyroxene } \\
\text { phyric fine- to medium-grained basalt. }\end{array}$ & $\begin{array}{l}\text { Titanomagnetite, } \\
\text { pyrrhotite }\end{array}$ \\
\hline 505B-2-1, 29-33 & 114 & 1 & $\begin{array}{l}\text { Chromite-bearing microlitic basalt with pheno- } \\
\text { crysts of olivine and plagioclase; olivine is } \\
\text { fresh, even in the groundmass. }\end{array}$ & $\begin{array}{l}\text { Spinel, } \\
\text { titanomagnetite, } \\
\text { pyrite }\end{array}$ \\
\hline $505 \mathrm{~B}-6-1,112-114$ & 218 & 1 & $\begin{array}{l}\text { Chromite-bearing, medium-grained basalt with } \\
\text { phenocrysts of plagioclase and olivine; oliv- } \\
\text { ine is fresh in phenocrysts, but is entirely } \\
\text { replaced by light-colored smectite in the } \\
\text { groundmass. }\end{array}$ & $\begin{array}{l}\text { Spinel, } \\
\text { titanomagnetite, } \\
\mathrm{M}_{\mathrm{SS}}, \mathrm{I}_{\mathrm{SS}} \\
\text { magnetite }\end{array}$ \\
\hline
\end{tabular}



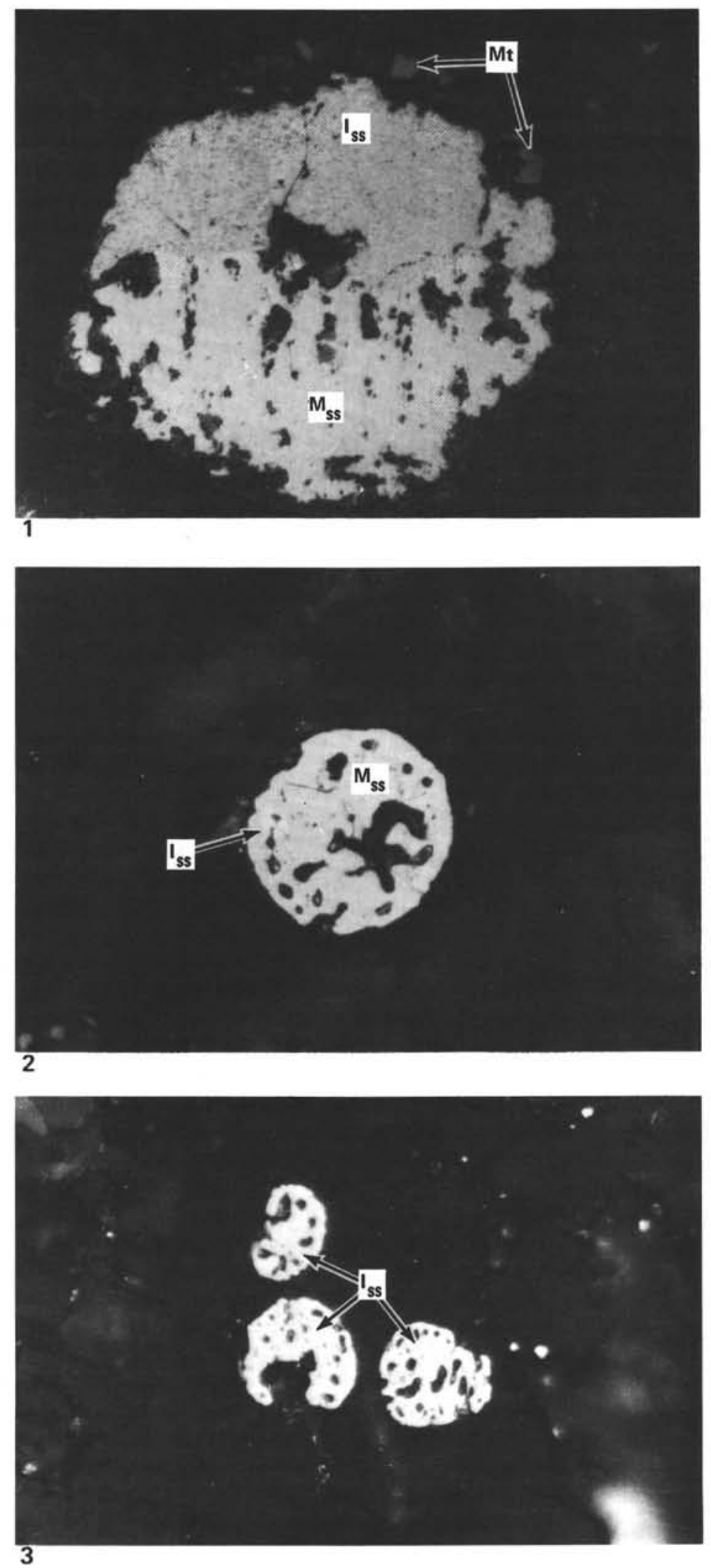

Plate 1. Morphological peculiarities and internal structure of sulfide globules. 1. Two-phase globule consisting of iron-copper $\left(\mathrm{I}_{\mathrm{ss}}\right)$ and ironnickel $\left(\mathrm{M}_{\mathrm{ss}}\right)$ sulfide solid solutions. The upper part of the globule contains grains of titanium-free magnetite (Mt); 505B-6-1, 112-114 cm; Sample 218. 2. Sulfide globule with silicate inclusions (dark), consisting mainly of quenched iron-nickel solid solution $\left(\mathbf{M}_{\mathrm{ss}}\right)$ and a moderately small amount of iron-copper solid solution $\left(\mathrm{I}_{\mathrm{ss}}\right)$; 504B-36-3, 120-123 cm; Sample 325. 3. Skeletal globules with silicate inclusions (dark) consisting of copper-iron solid solution $\left(\mathrm{I}_{\mathrm{ss}}\right)$. 504B-36-3, 120-123 cm; Sample 325. 


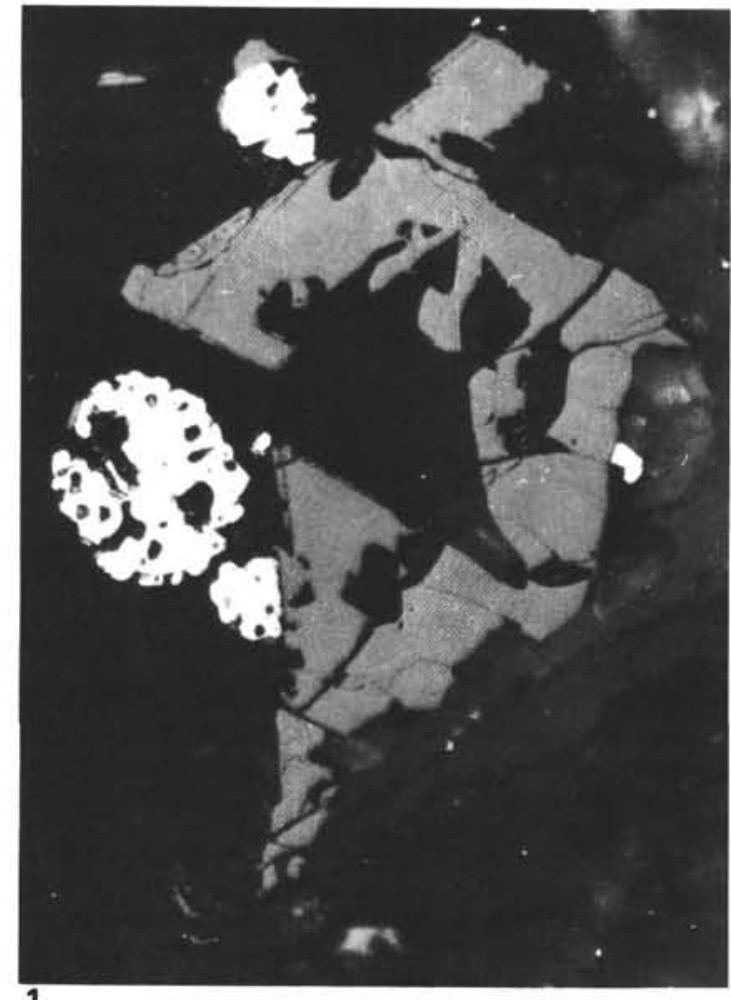

1

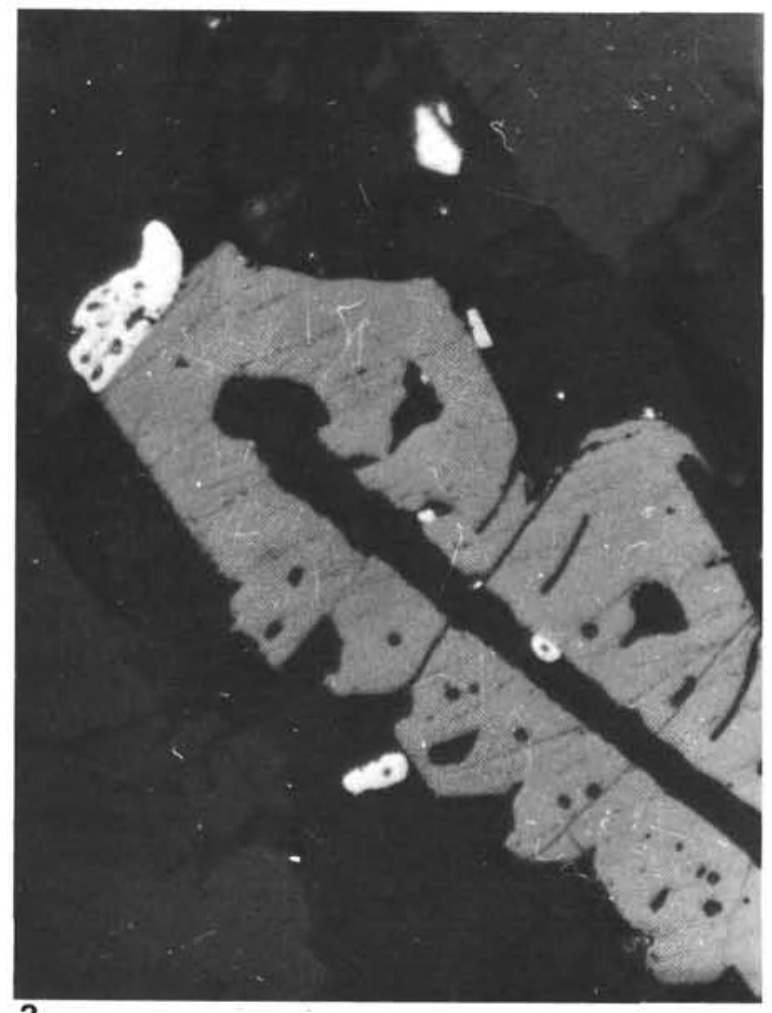

2

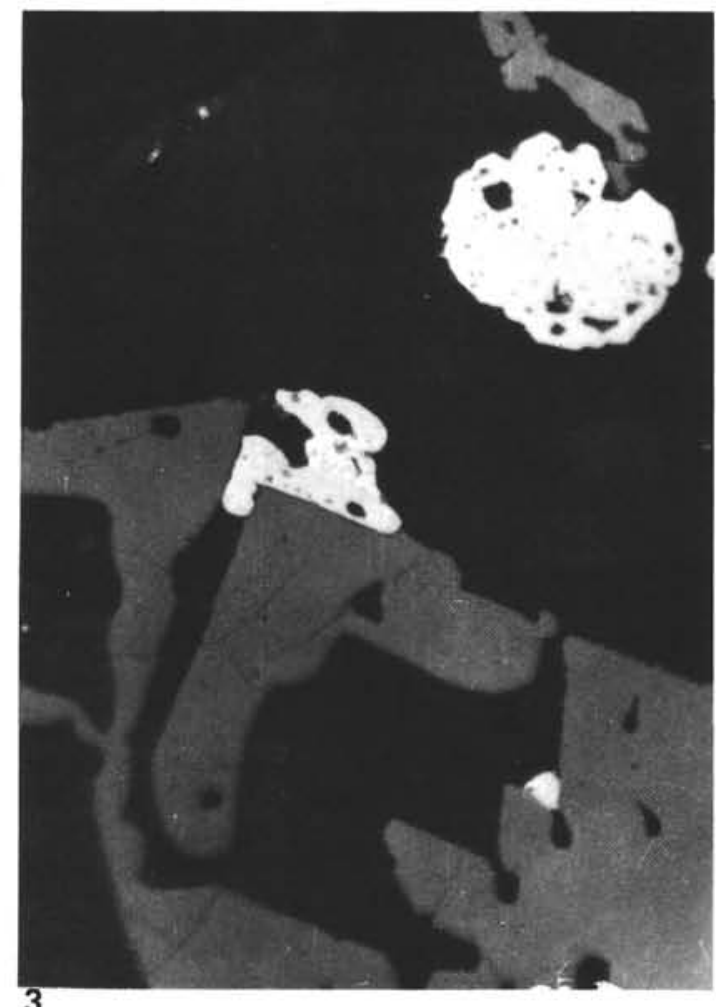

3

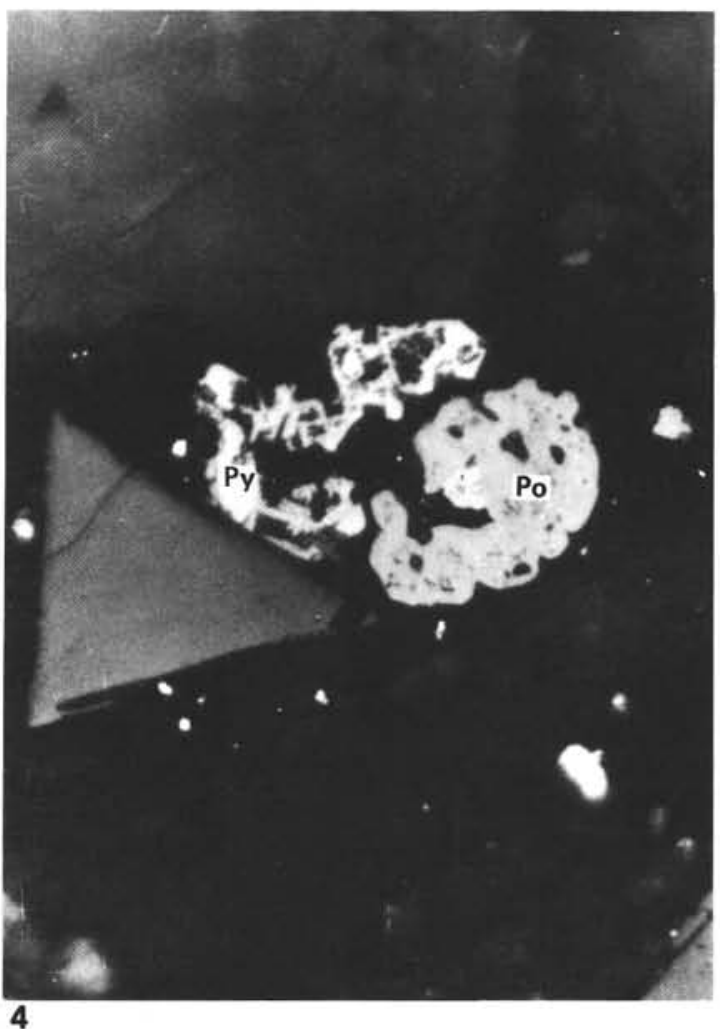

4

Plate 2. Sulfide globules with titanomagnetite and chromian spinel. 1-3. Distortion of the rounded shape of sulfide globules (white) at contact with titanomagnetite (gray), caused by an earlier crystallization of the oxide phase. The shape of the globule in 3 is the result of flowing of sulfide liquid into interstices of titanomagnetite grains. 1. 505B-2-1, 29-33 cm; Sample 114. 2. 505B-6-1, 112-114 cm; Sample 218. 3. 504B-57-3, 107-110 $\mathrm{cm}$; Sample 1178. 4. Pyrrhotite (Po) globule (light gray) partly replaced by pyrite (Py, white) intergrown with chromian spinel (gray); 504B, 36-3, 120-123 cm; Sample 325. 


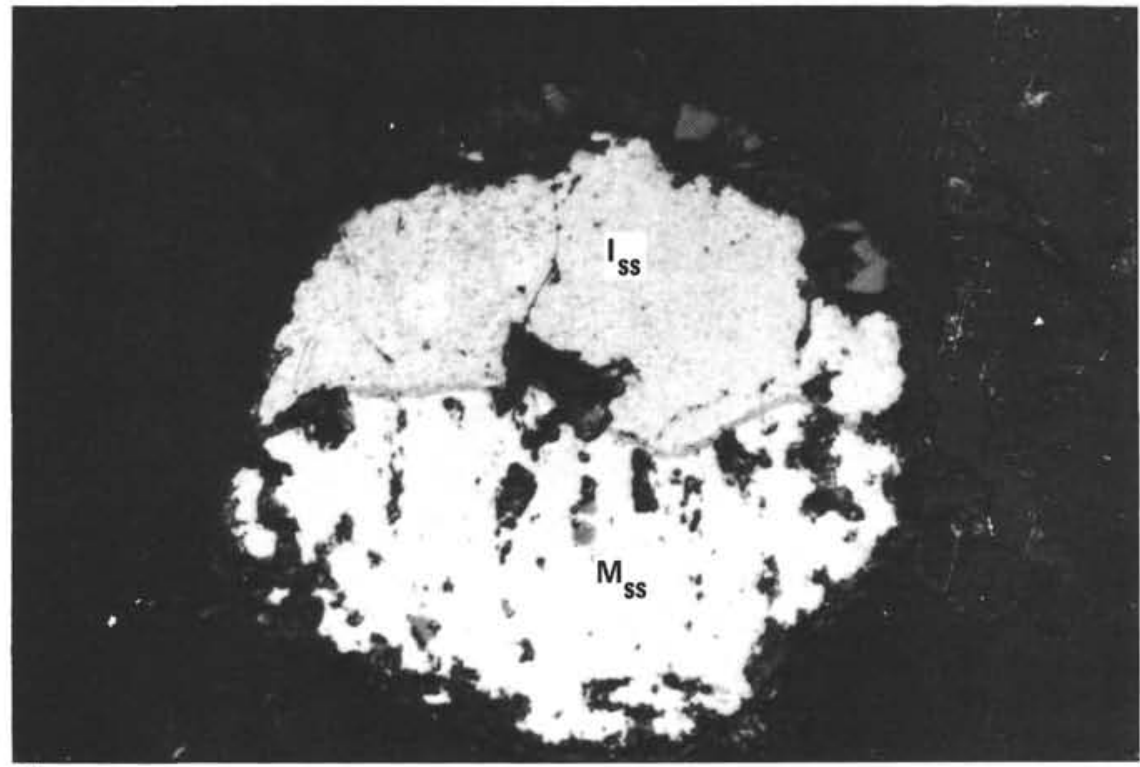

1

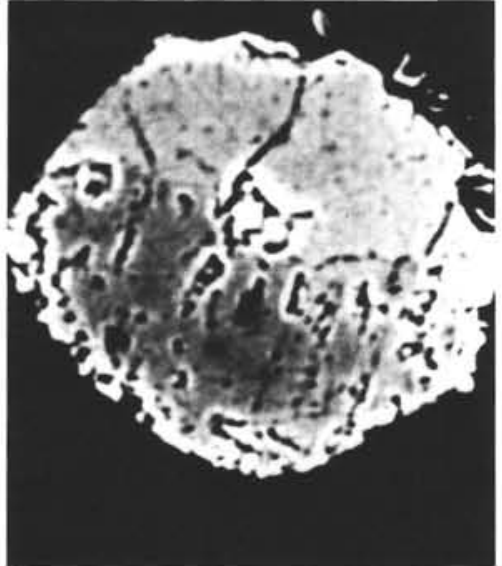

2

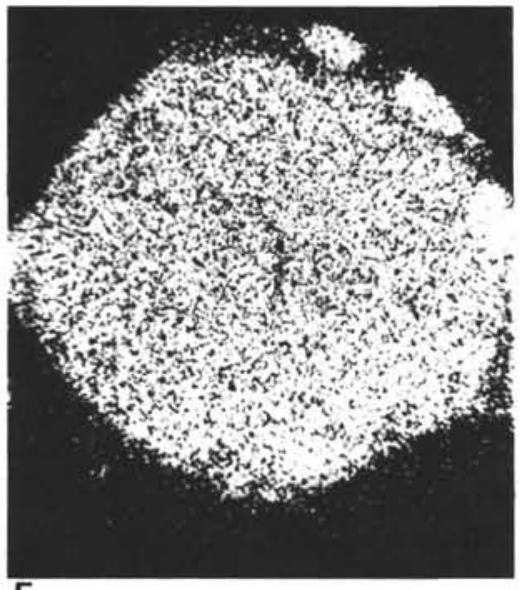

5

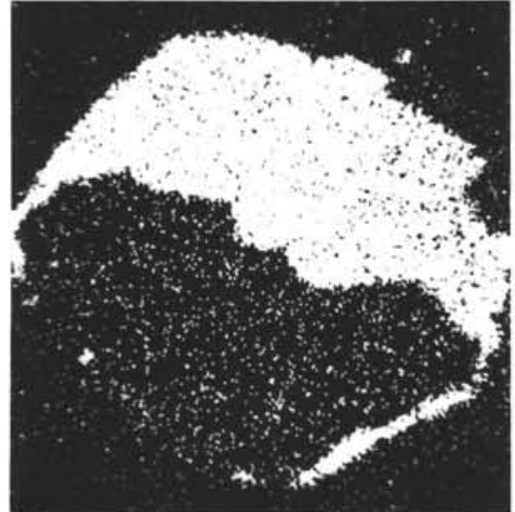

3

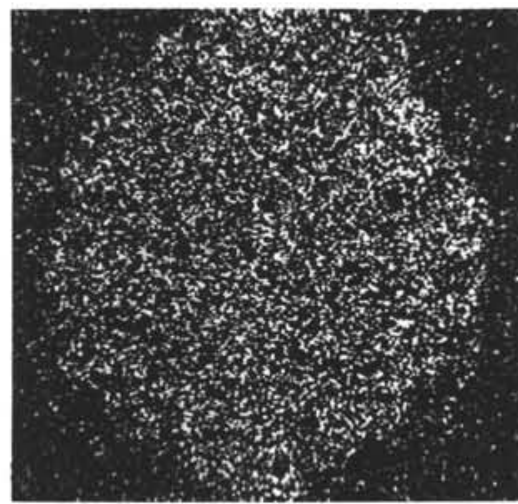

6

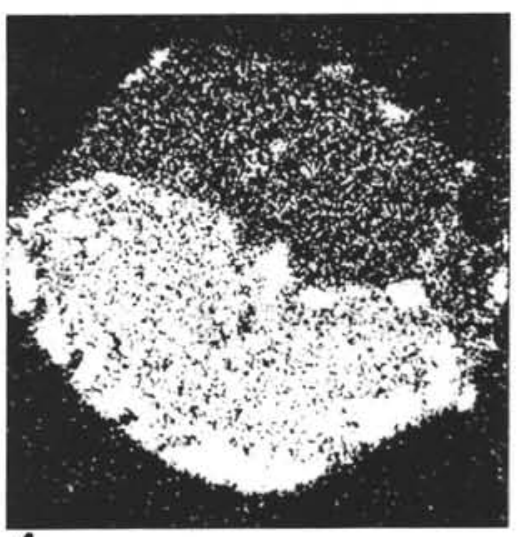

4

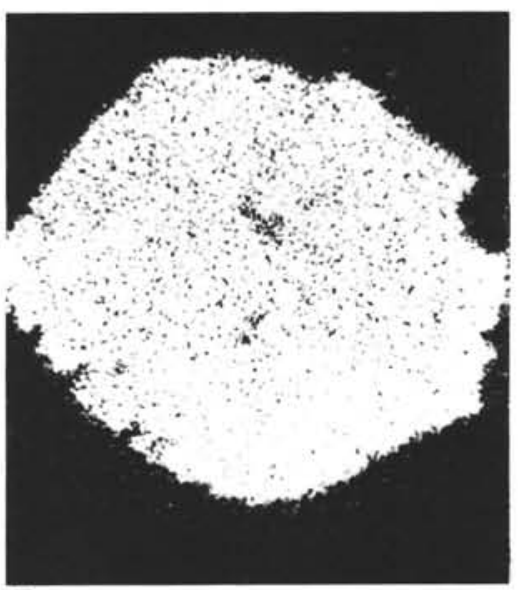

7

Plate 3. Characteristic X-ray scans of a layered sulfide globule consisting of quenched copper-iron $\left(\mathrm{I}_{\mathrm{ss}}\right)$ and iron-nickel $\left(\mathrm{M}_{\mathrm{ss}}\right)$ sulfide liquids; 505B6-1, 112-114 cm. The boundary between the two quenched liquids and inflowing of copper-iron liquid along the border with silicate matrix are clearly pronounced. Distribution of elements, except $\mathrm{Ni}$ and $\mathrm{S}$ esriching the bottom part, is uniform in both parts of the globule. 1 . Reflected light image. 2. Backscattered electron image. 3. Copper $K_{\alpha}$ scanning image. 4. Nickel $K_{\alpha}$ scanning image. 5. Iron $K_{\alpha}$ scanning image. 6. Cobalt $\mathrm{K}_{\alpha}$ scanning image. 7. Sulfur $\mathrm{K}_{\alpha}$ scanning image. 

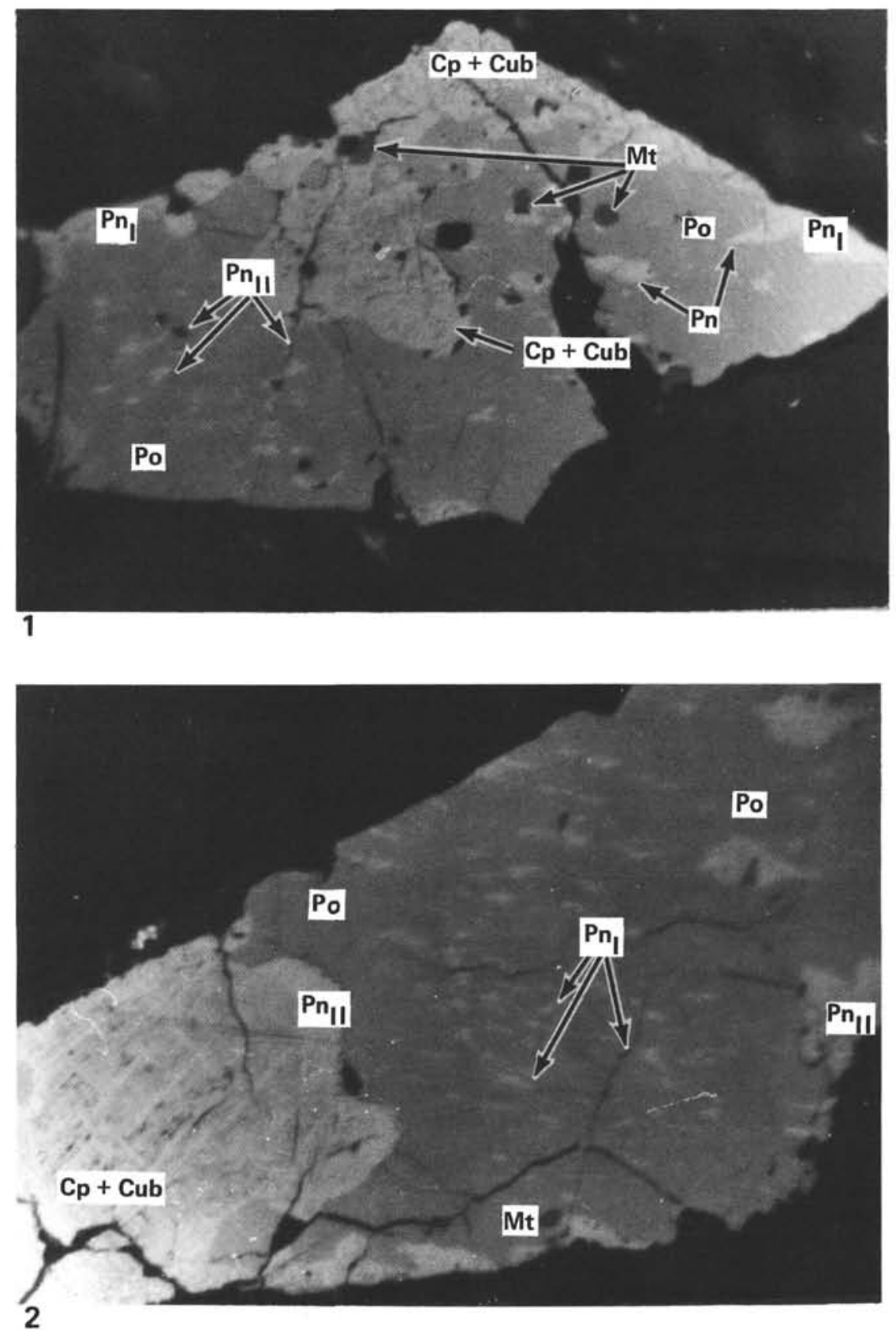

Plate 4. Sulfide growths in multi-phase aggregates. 1. Grains of first generation pentlandite $\left(\mathrm{Pn}_{\mathrm{I}}\right)$ and the rims, lamellar and flame-like aggregates of pentlandite of the second generation $\left(\mathrm{Pn}_{\mathrm{II}}\right)$ in pyrrhotite $(\mathrm{Po})$ containing rounded aggregates of titanium-free magnetite $(\mathrm{Mt})$. Cubanite (Cub) lamellae are present in chalcopyrite (Cp). 2. Cubanite-chalcopyrite and pyrrhotite-pentlandite growths. First generation pentlandite grains $\left(\mathrm{Pn}_{\mathrm{I}}\right)$ are also apparent. 504B-57-3, 107-110 cm; Sample 1178. 

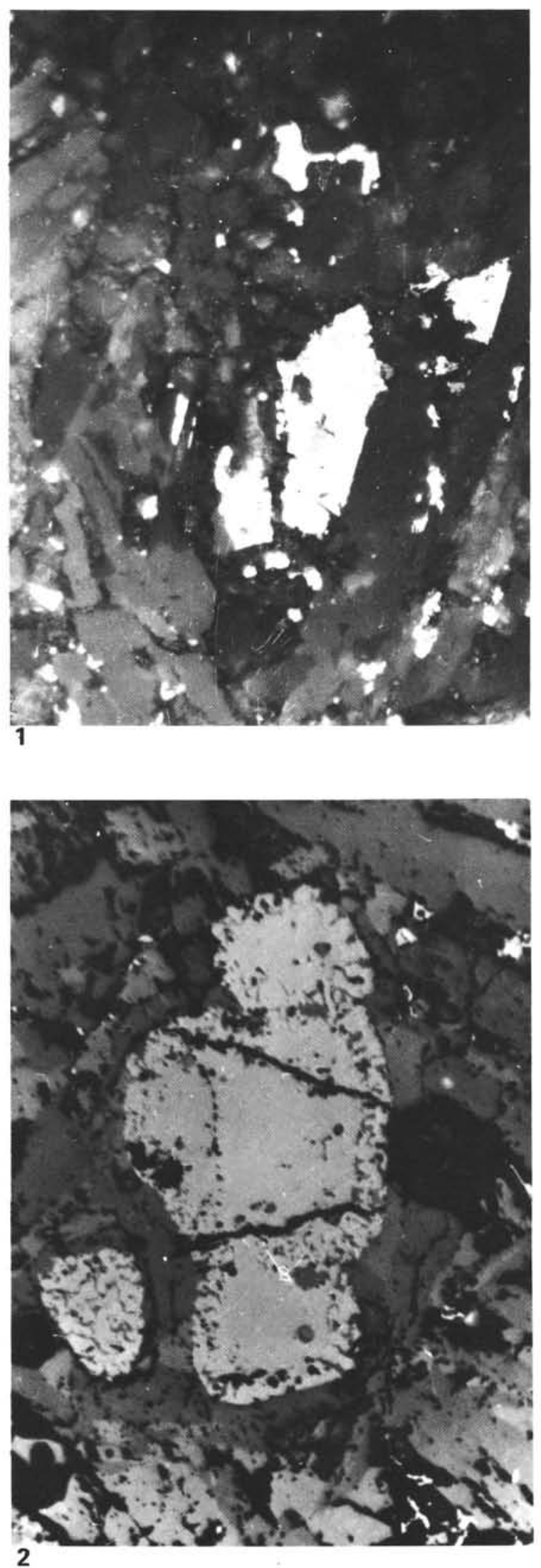

Plate 5. 1. Skeletal titanomagnetite crystal (dark) in pyrite; 504B-7-3, 116-120 cm; Sample 488. 2. Zoned crystal of chromium spinel. 505B-6-1, $112-114 \mathrm{~cm}$; Sample 218. 